\title{
"Forward to the bright future of socialism!": the role of images and symbols in promoting collectivization in Soviet Ukraine
}

\author{
Oksana Zhukova ${ }^{1,1}$ \\ ${ }^{1}$ Estonian University of Life Sciences, Tartu, Estonia
}

\begin{abstract}
In every country, state symbols such as the national flag, emblem, and national anthems represent the independence and sovereignty of the state. In the Soviet Union as well as in other autocratic states symbols also played an important role in propaganda, influencing peoples' attitudes to the actions of the state at all levels. These symbols could also be found, together with powerful imagery in posters, on buildings, monuments and many other things visible and incorporated in the routine life the people. Ukraine has huge historical heritage of symbolism and propaganda from when the country was a major part of the USSR. After the creation of the USSR a political, socio-economic, cultural and spiritual experiment on the construction of a communist society, which in the case of Ukraine was unprecedented in scale and tragedy, began. The collectivization of the village is one of the most tragic pages in the history of Ukraine. As the most important grain-growing region of the country at the time its production was vital to feed the growing cities and industrialisation. The forced collectivisation led to starvation in the 1930s and millions of people died. In order to counter this most public information showed people another side of collectivization. Propaganda was used, such as posters and slogans, to persuade the peasants to join the collective farms and to promote the real or fictitious results of the workers, and, conversely, to attack people who did not want to believe in the "bright future" of the USSR and to denounce "kulaks" and "saboteurs". Materials from archives and published sources show many examples of Ukrainian images and symbols of that time which shed a light on the way the collectivisation process was portrayed and promoted.
\end{abstract}

\section{Introduction}

The defeat of the national-liberation revolution in Ukraine in 1920 enabled Soviet power to be established. The desperate attempt of the Ukrainian people to put an end to Bolshevik-Russian oppression was defeated during the civil war in the Ukraine in 19171920. After the creation of the USSR in 1922, a political, socio-economic, cultural and spiritual experiment, unprecedented in scale and tragedy, began. This paper describes

\footnotetext{
${ }^{1}$ Corresponding author: oksana.zhukova@emu.ee
} 
the process by which collectivization of agriculture was forced on the Ukrainian peasantry and the role of the arts, propaganda and symbolism in legitimising the regime and creating a cooperative populace. It is based on a review of literature and illustrated with materials from various archives as well as that collected on site visits to Ukrainian former collective farms [1].

\section{The context of collectivisation in Ukraine}

The policy of complete collectivization of agriculture across the USSR was officially announced in November 1929. In the following January, the terms of collectivization were determined for different regions of the country. Ukraine was placed in the second group of regions where collectivization was planned to be completed by the autumn of 1931 or the spring of 1932. To carry out industrialization, Josef Stalin, who had recently achieved complete control of the USSR, needed millions of workers as well as food and currency to enable the import of Western technology and factory equipment. The main Soviet exports during the first five-year plans were food and timber. Food to feed the cities and for export was brutally seized from the villages almost free of charge. It resulted in a drop in the standard of living of the population to a starvation level.

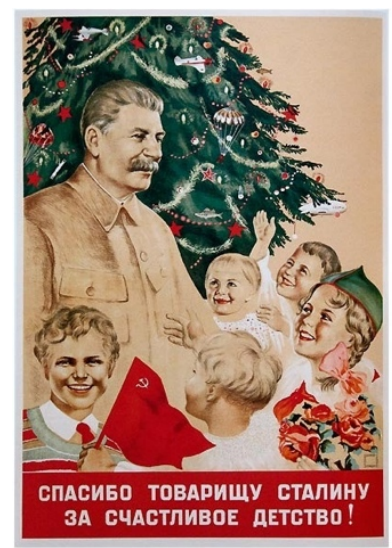

Fig. 1. Poster. Stalin depicted as a kind of Father Christmas, friend to all children.

VATOLINA, N.; DENISOV, N.; GRIGOREVICH PRAVDIN, V. et al. 1938. Спасибо товарищу

Сталину за счастливое детство! [Spasibo tovarishchu Stalinu za schastlivoye detstvo! / Thank you comrade Stalin, for our happy childhood!], Moscow-Leningrad, Ogiz Izogiz. (Souce ${ }^{2}$ :

Russian State Library, IZO П6)

The social structure of the Ukrainian village, of which the peasantry constituted the major proportion of the population of Ukraine, was unique. The number of rural residents was four times that of urban residents $(82-83 \%$ compared to $17-18 \%$ at the end of the 1920s). This part of Ukrainian society was the keeper of the traditionalist mentality which was individualistic and focused on farming, with little sympathy for the socialist doctrine and collective forms of agriculture promoted by the Bolshevik revolution. The Ukrainian village was viewed as a place with an ideal peasant culture and peasant values. The kulak (the richer peasant - literally the "closed fist") was the main person in the village, not because he enslaved others, but because he possessed a moral authority over the other peasants due to his diligence, thrift, honesty and piety - all aspects hated by Communist agitators.

\footnotetext{
${ }^{2}$ Retrieved from : https://4.404content.com/1/21/9D/1523127585505543578/fullsize.jpg
} 
There were neither communist cells nor any particular political life in the villages. The concerns of the Soviet government and its ideology remained beyond the interest of most Ukrainian peasants. The church was the main focus of the spiritual life of the village. The church in the USSR by the 1920 s was fundamentally different from the prerevolutionary one: it was deprived of its property and the priest and church buildings were kept up by the peasants. The church thus became an element of peasant culture and peasant society. The priest became the guardian of the spiritual version of peasant values. Socially, the priest and his family were close to the kulaks and thus the real political and moral core of the village [2: 31-32].

The establishment of absolute power by the Communist party and the merging of its functions with those of the state bodies formed the essence of the Soviet political regime of the 1930s which had by then become a dictatorship of Josef Stalin. One of the elements of this was the cult of Stalin's personality. He began to be called "wise", "great", and "ingenious", the "father of nations" and "the best friend of Soviet children".

The socio-political regime had two social bases: one, active, was the immediate surroundings of the communist leader and the Soviet party nomenklatura on the ground; the other: the other, passive, was workers, the rural poor, part of the middle peasantry, marginal layers of the village and the city. The Stalinist regime relied on a rigid authoritarian ideology covering all spheres of social life. It was based on MarxismLeninism, but more simplified and modified. The propaganda of Leninism served to transform it into an object of faith, into a kind of new socialist religion. At the same time, Stalin, who was called the "Lenin of our day" from 1929, sought to unite his life and work with the revolution, Bolshevism and Leninism in the people's minds.

\section{The ideology of collectivisation}

According to the Soviet doctrine of collective farm construction, the poor were allies of Soviet power, the kulaks were its enemies and the middle peasants were the kulaks' fellow travellers. The poor peasants constituted the bulk of the rural population and the success of the socialist transformations of the agrarian sector of the economy - which largely depended on grain from Ukraine - relied on the position that they would take: whether they would join collective farm construction or continue individual farming.

The middle peasants were at a crossroads: they did not hurry to join the ranks of active builders of the "collective farm paradise", nor did they oppose the expanded collectivization for which they saw no benefits. At the same time, being experienced and far-sighted, they understood that they would not be able to sit out the process in a quiet backwater of individual farming: the bolsheviks would come for them, and if they refused, they would be crushed.

The country's leaders paid great attention to the ideological provision of collectivization. A large propaganda apparatus was used for the campaign. The idea of the need for collectivization and its role in building socialism in the country was constantly evoked on the radio, in the pages of newspapers, at rallies and meetings. All dissenters and doubters were added to the ranks of "socially hostile and backward" elements, "reincarnated ones and counterrevolution supporters", "bloodsuckers, kulaks and podkulachniki" - "oppressors of the working peasantry". The term kulak became a common nickname, a stigma of apostasy, a symbol of everything hostile, alien and despicable (Fig. 2). The range of genres used in the authorities' ideological efforts was so wide, and the propaganda itself was so active that even such conservative forms of folk expression such as proverbs and sayings suddenly manifested themselves as a multitude of anonymous rhymes or slogans on the most burning issues of the day: 
"Kulaks are kicked off - their backs are unbent",

"The collective farm force is the kulaks' grave",

"It is not without reason that the kulak is afraid of the collective farm",

"On paper - poor, by deeds - harmful",

"A Soviet poor man's work is seen from afar",

"Do not be a child - fight with the kulak and lose",

"We must all know how to recognize the kulak"

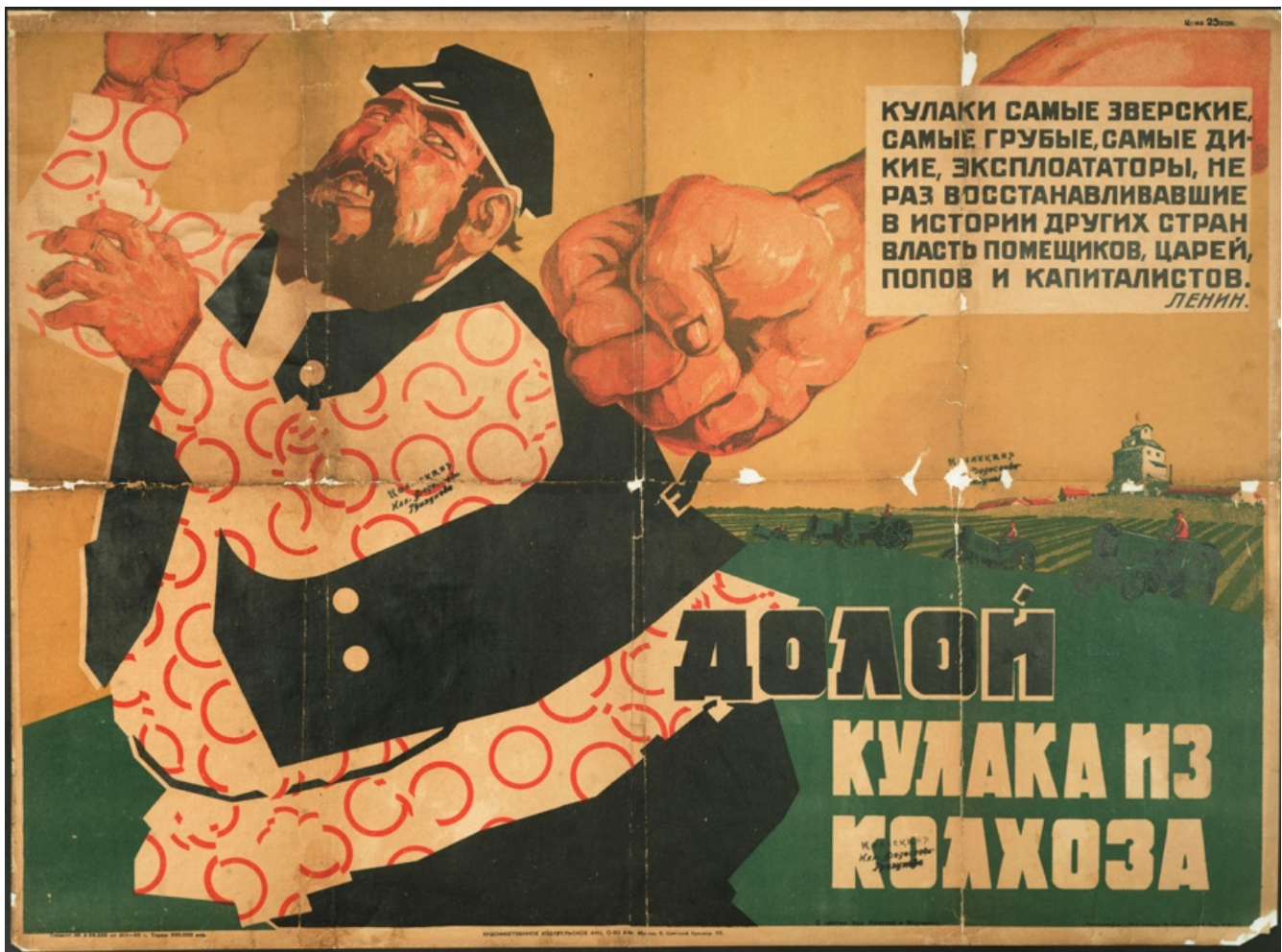

Fig. 2. Poster showing the kulak as fat and greedy. IVANOV, A.; MIRZOYANTS, Sh.A. 1930.

Долой кулаки из колхоза [Doloy kulaki iz kolkhoza / Down with kulaks in kolkhozes]. (Source: LSE Library's archive, Coll Misc 0660/2/1 ${ }^{3}$ ).

In the1920s-1930s in Ukraine anti-Stalinist sentiments among the workers and intellectuals were particularly troubling for Moscow, as they strengthened the anticollectivisation sentiments [3]. Vivid examples of people's hatred of the Communists were found in poems, proverbs and songs of a political nature. Thanks to the hypertrophied support of the poor peasants by the Soviet authorities and an allembracing and well-developed propaganda, a real "cult of the poor" was created. Here it is appropriate to give an eyewitness account of those events.

"The cult of the poor," he noted,

produces pretenders ("chemists", as they are called in the village), who in full consciousness, in the sight of all, do not have their livestock and implements; for two years, they do not cover the roofs and live like samoyeds on the threshing floor. This also forces strong families to settle apart, so that everyone immediately becomes poor and starts eating other people's

\footnotetext{
${ }^{3}$ Retrieved from: https://www.flickr.com/photos/lselibrary/3273571261/in/photostream/
} 
bread. Shame and disgrace should not be on the so-called kulaks and the well-to-do who have their own bread, but on those "chemists", the poor who, after 10 years of having the equal amount of land, still do not want to work properly and artificially support their poverty and hunger in the hope of state aid. Is not it a shame! The cult of the poor must be changed at the root, otherwise they, like Pharaoh's skinny cows, will devour all the fat and will not get fat themselves. Parasitism and pretence have to be pulled out by the roots" [4].

The Soviet government saw its most important task as displacing the conservative, primarily Orthodox, worldview and substituting for it a socialist-atheistic system. This necessarily had its own iconography, creation myth, prophets and other elements otherwise associated with the religion - headed up by the father figure of Stalin. The socialization of peasants and their labour as realized by the government necessitated the overcoming of individualism of single producers and their unification into collective economic entities. In order to strengthen the argument for the planned activities, the continuity of the centuries-old practice of communal living of the peasantry was converted into the new collective forms of organization of life and work in the countryside. It should also be noted that forced collectivization in Ukraine took place according to the Russian scenario, without taking into account the national characteristics and traditions of the local Ukrainian population.

Theoretically, the Bolshevik doctrine of agrarian construction was similar to the concepts of leading Russian scientists in the field of agriculture - such as Kondratiev, Chayanov, Chelintsev and others - who developed the ideas of traditionalism in organizing peasant life, preserving the community-based organization of labour, ensuring economic initiative and freedom in Russia, but not in Ukraine. To some degree the positions of Russian scholars and Bolshevik theorists headed by Bukharin were close, but in practice the Soviet authorities proceeded along the path of administration and the rigid introduction of a unified scheme for cooperation throughout the country without taking into account regional peculiarities.

\section{The ideological conversion of the peasantry}

The ideological conversion of culture and all aspects of life resulted in the need for respect for the principle of party art. Literature, painting and music had to reflect the revolutionary struggle of the proletariat and the successes of building socialism and to educate the Soviet people in the spirit of devotion to the Party and Communism. All aspects of life received an ideological justification, and a class approach was also proclaimed in science. The party and state control over all spheres of social life was also established. The Party, the Komsomol, the Pioneers, state trade union organizations, formally non-governmental but in fact led by the party together with stateowned unions of writers, composers and artists - these and other organizations, voluntary societies, including housing block management, covered all ages, social and professional groups of the Soviet people. They controlled all aspects of society and its individual members. Even private life, including family life, could become a subject of discussion and condemnation at public meetings. The party organs mobilised the peasants to march in support of collectivisation (whether they wanted to or not) (Fig. 3). 


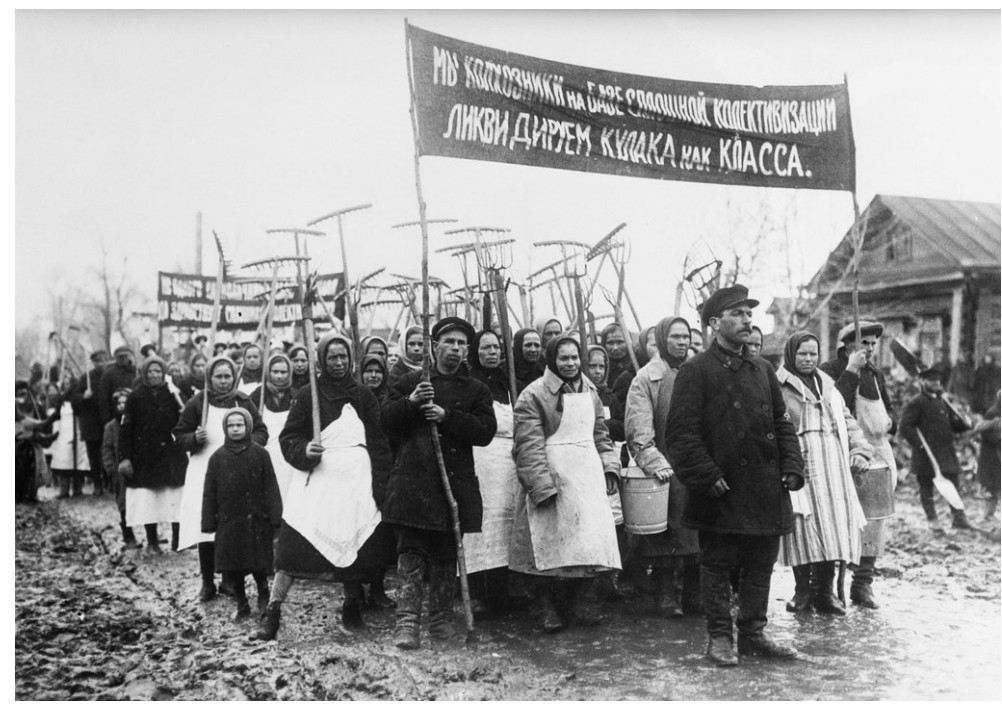

Fig. 3. Peasants marching beneath a banner denouncing kulaks. (Source: State Museum of the Political History of Russia)

The cultural revolution led to the formation of a "new type of consciousness" and a "new man", on the one hand, inspired by the idea of a bright future, confident of the correctness of the general line of the party, and, on the other, forced to be constantly afraid of becoming a victim of error and the arbitrariness of punitive agencies. A special role was played by party control over the media through which the official views were disseminated and explained. With the help of the external border control - later the "Iron Curtain" - the problem of other ideological views penetrating society from outside was broadly solved [5].

The education system also underwent changes. The structure of curricula and the contents of training courses were completely restructured. They were based now on the Marxist-Leninist interpretation not only of social sciences, but also of natural sciences.

\section{The Holodomor}

Along with ideological institutions, the totalitarian regime had another reliable support a system of punitive agencies for persecuting dissenters. In November 1934, a Special meeting was set up at the People's Commissariat of Internal Affairs (NKVD), which was given the right to send "enemies of the people" to administrative exile or to forced labour camps for up to five years. An active struggle against "kulaks" and "liquidation of the kulaks as a class" began. In practice, this meant the physical destruction (death) of wealthy peasants (Fig. 4). During the years of collectivization in Ukraine, about 200,000 peasant farms were destroyed. Together with family members, it amounted to approximately $1,500,000$ people. The vast majority of them were deported to the Far North and Siberia, where many of them died. Forced collectivization with the socialization of almost all property, repression and arbitrariness, dekulakization, which affected the interests and fate not only of the well-to-do peasants, caused discontent and mass actions in the Ukrainian village. According to some reports, in the villages of Ukraine in 1930 there were more than 40,000 uprisings and riots [6: 101]. 


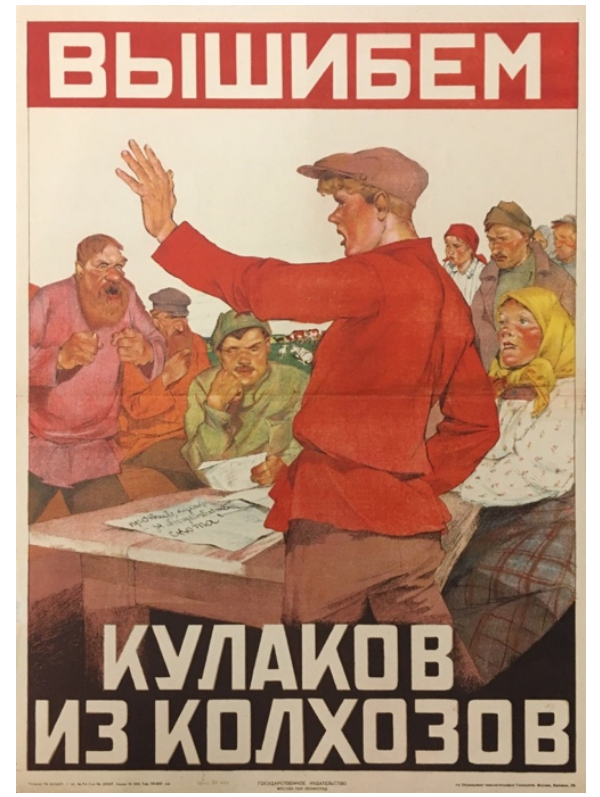

Fig. 4. Poster depicting the expulsion of the kulak from the kolkhoz [he eventually went to Siberia or elsewhere...]. Вышибем кулаков из колхозов [Vyshibem kulakov iz kolkhozov / Kick the kulaks out of the collective farms] (ca. 1930). Moscow, Gosizdat. (Source ${ }^{4}$ : State Museum of the Political History of Russia, Ф.V-1394/1)

The direct result of forced collectivization was the Holodomor in Ukraine of 19321933, which was genocide of the Ukrainian people by forced starvation. The main cause of the 1932-1933 Holodomor was a purposeful criminal policy by the Bolshevik leadership. The Stalinist authorities purposefully destroyed the Ukrainian peasantry, the vast majority of which was hostile to the communist occupation regime in Ukraine and to collectivisation.

The famine, which spread in Ukraine during 1932, increased significantly in early 1933. According to the estimates of researchers, in Ukraine 25 thousand people a day died of starvation, 1000 every hour, or seventeen every minute (Fig. 5). In the wake of the Holodomor a radical reconstruction of the Ukrainian village in the early 1930s predetermined the development of Soviet agriculture for all subsequent decades. At the same time, the defects of the socialist model of the collective labour of the peasants began to show themselves over the years [7: 15]. Occasional corrections, repeatedly introduced into the agrarian policy, could not adapt the collective farm system to the changing social and political situation. This was one of the reasons for the systemic state crisis and the subsequent destruction of the Soviet Union.

\section{Rebuilding the identity and propagandising the people}

In the post-Holodomor era, and especially in the post-Great Patriotic War (World War II) phase, during which Ukraine was occupied by the Germans and subject to enormous destruction, reconstruction physically and morally was needed and this had a major impact on the kolkhoz. Already in the 1930s propaganda and the use of symbols, posters, music and Socialist-realist art had played a role in building the new nation within the

\footnotetext{
${ }^{4}$ Retrieved from :

https://upload.wikimedia.org/wikipedia/commons/e/ef/Вышибем_кулаков_из_колхозов_1930.jpg
} 
USSR. The flag of Ukraine combined a sunrise with enclosing sheaves of wheat, symbolising the grain production of this bread-basket of the USSR (Fig. 6) with its mottos

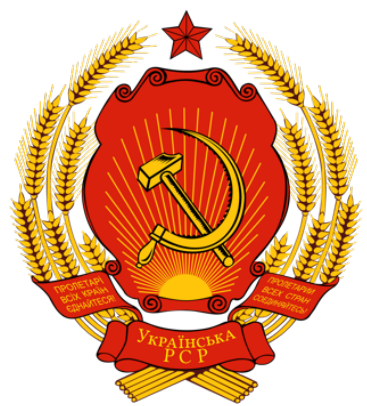

Fig. 6. The state symbol of the Ukrainian SSR (1949-1990): The bounty of the wheat harvest surrounding the rising sun. (Source: Wikimedia Commons ${ }^{5}$ )
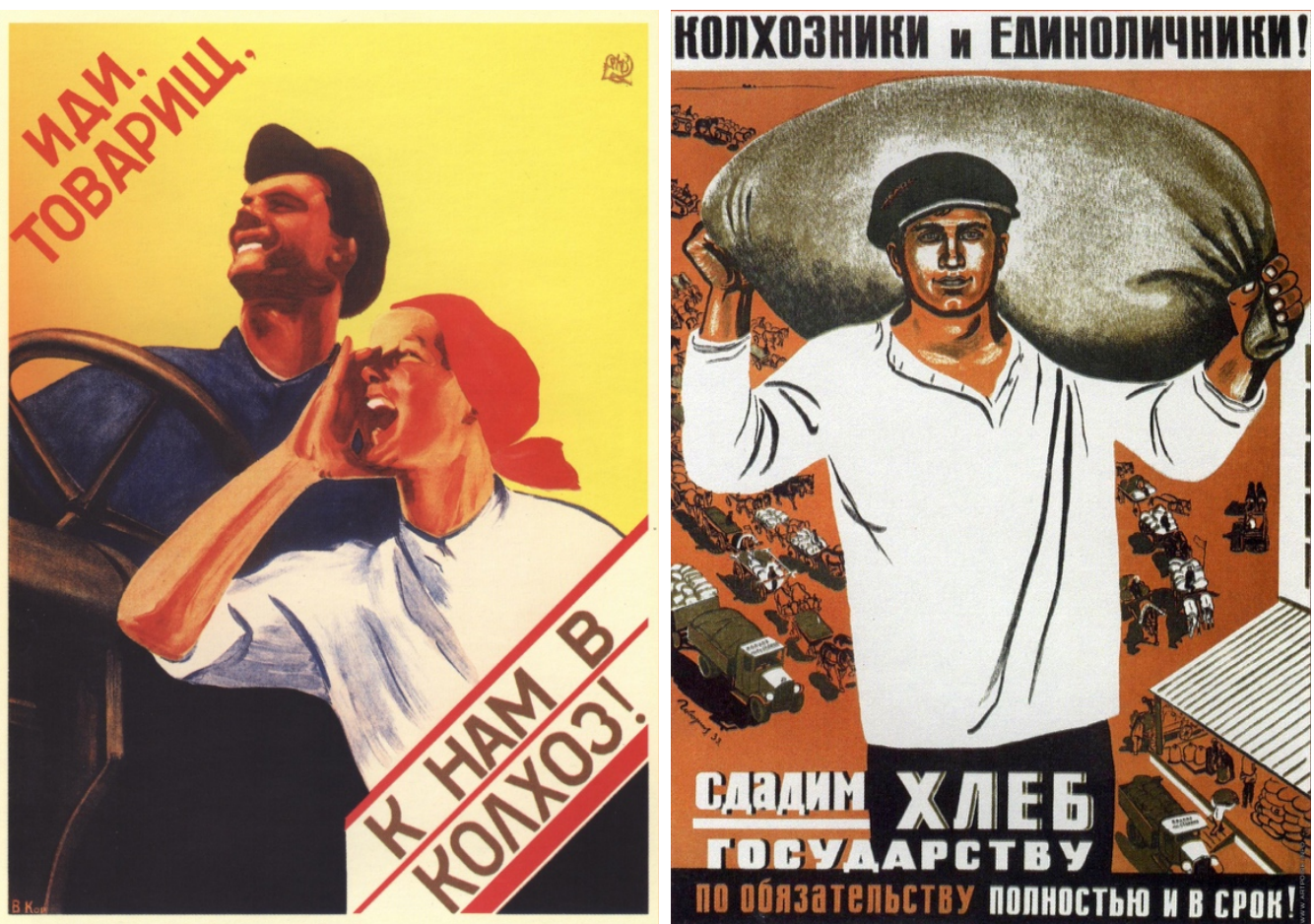

Figs. 7a, b. Posters promoting the kolkhoz featuring strong, willing and happy workers.

(a) KORABLEVA, V. 1930. Иди, товарищ, к нам в колхоз! [Idi, tovarishch, k nam v kolkhoz! /

Comrade, Come to Our Collective Farm! - (b) GOVORKOV, V. 1933. Колхозники и

единоличники! Сдадим хлеб государству по обязательству полностью и в срок! [Kolkhozniki i yedinolichniki! Sdadim khleb gosudarstvu po obyazatel'stvu polnost'yu i v srok / Kolkhozniks and individual peasants! Let's supply bread to the state!] (Sources ${ }^{6}$ : Russian State Library)

\footnotetext{
${ }^{5}$ Retrieved from: https://commons.wikimedia.org/wiki/File:Emblem_of_the_Ukrainian_SSR.svg

${ }^{6}$ Retrieved from: (a)

https://www.historyworlds.ru/uploads/gallery/main/261/sovpolpost_00039_1_2.jpg - (b)

http://artpoisk.info/site/downloadimage/24726/
} 


\section{Propaganda materials in print}

Typical propaganda of the period appeared on posters to exhort the peasants and workers to come to the kolkhoz and join in with the collective efforts towards the bright future of socialism (Fig. $7 a$ and b). These are graphically very effective.

To garner support there was a magazine published aimed at kolkhoz women, with covers celebrating the achievements of the new Soviet woman (Fig. 8).

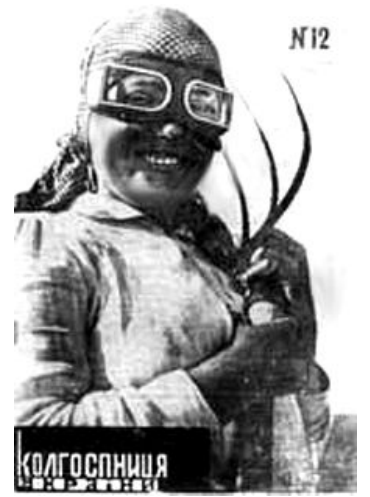

Fig. 8. Cover of the Soviet magazine Колгоспниця України Орган Відділу агітаціі и масових кампаній ЦК КП(б)У [Kolhospnytsia Ukrayiny / Collective Farm Woman of Ukraine: Organ of the Department of Agitation and Mass Campaigns of the Central Committee of the Communist Party of Ukraine), $n^{\circ} 12,1932$. (Source ${ }^{7}:[8]$ )

\section{Socialist realist art and the kolkhoz}

Socialist realist paintings of the kolkhoz often depict landscapes - one of the few uses of the genre in the medium - and continue in style right up until the 1970s [5] (Fig. 9).

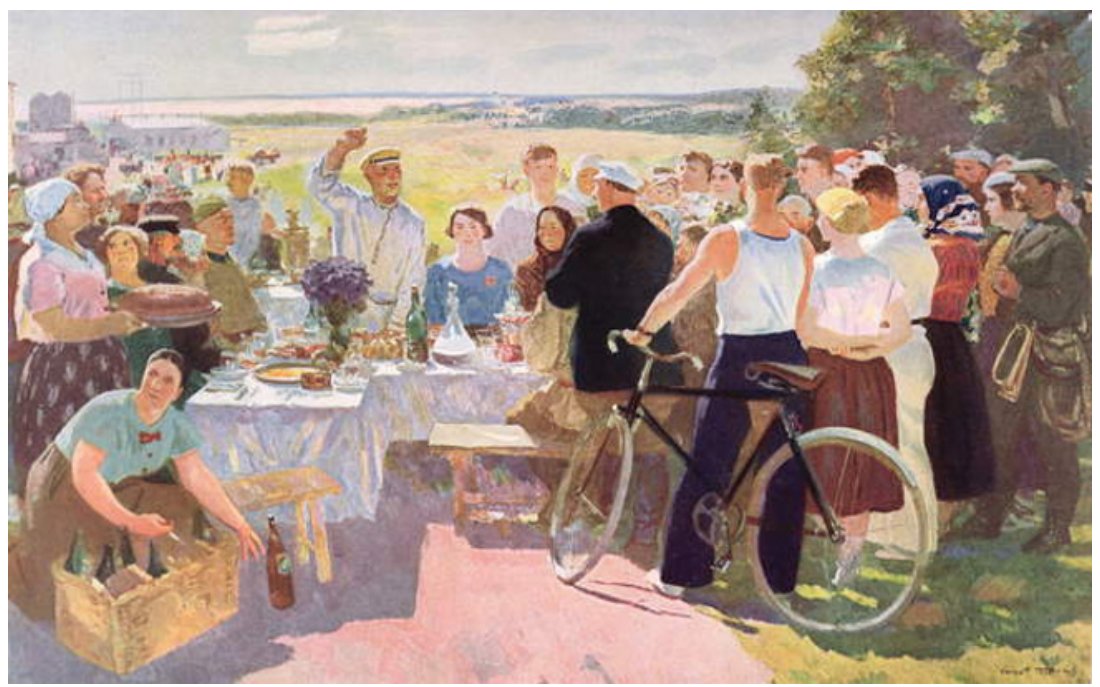

Fig. 9. Figure 9: GUERASSIMOV, S. 1937. Harvest Celebration at a Collective Farm, USSR. (Source: Private Collection / Archives Charmet / Bridgeman Images).

\footnotetext{
${ }^{7}$ Retrieved from: https://commons.wikimedia.org/wiki/File:Holodomor6.jpg
} 


\section{Symbols in architecture}

Until the advent of modernist architecture in the 1960s the main styles were Stalinistic classical. Such buildings often included typical symbols and slogans as part of the decoration. Figure 11 shows an administrative building with a slogan in ceramic tiles on one end (partly now damaged - the whole building is derelict). [3]

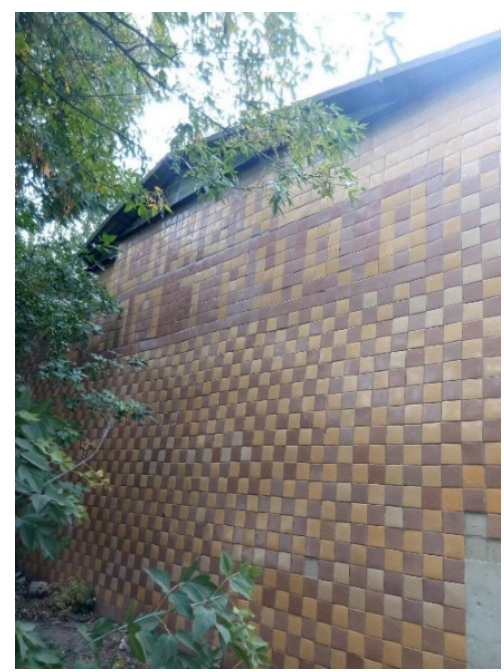

Fig. 10: A slogan in tiles forming an end wall of a Ukrainian kolkhoz building reads "Glory to the people of labour" (Source: the author)

Architecture also played an important role through the designs which aimed to present a healthy, suitable place for the new Soviet people to learn, work, live and play. Figure 12 shows one of a catalogue design for a kindergarten where, of course, the start of moulding children into good socialist citizens was started.

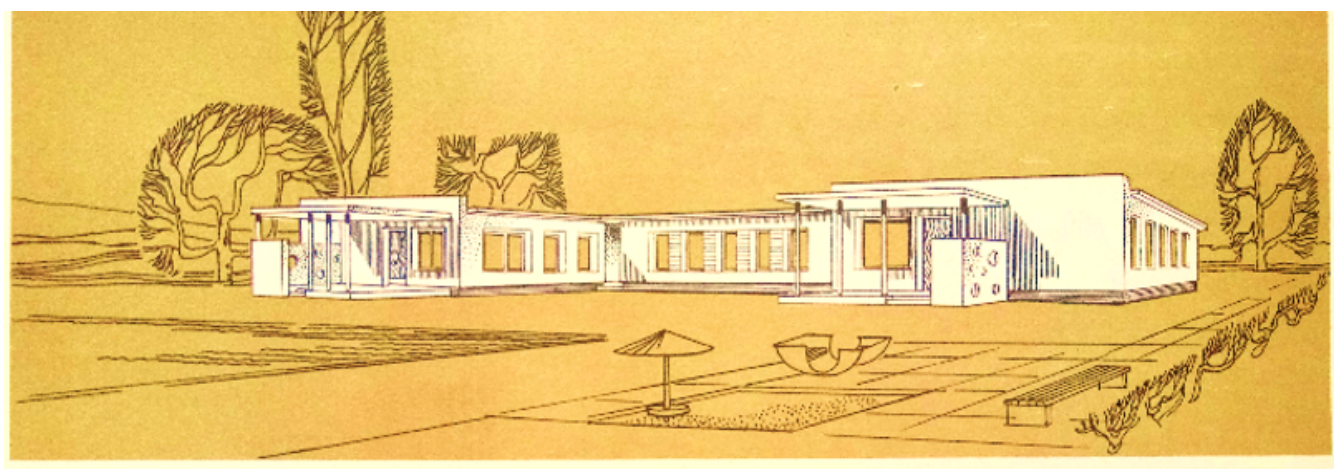

Fig. 12. A standard kindergarten design to accommodate 90 children. Standard project developed by the Institute "UkrNIIgiproselhoz" and Kiev ZNIIEP in 1968 (Rural Building Types

Project Album). 


\section{Discussion and conclusions}

The paper has presented a narrative of the process of forced collectivisation in Ukraine, the ideological struggle mounted by the Communist Party and the terrible sufferings by the peasants in the 1930s. All the arts were pressed into service but in the countryside and the kolkhoz specific forms of propaganda tended to be used to coerce and persuade the unwilling peasants to comply and to work to produce food from what was the bread basket of the USSR.

In this paper, we have tried to present the connections between the process that went on and the way that the propaganda and ideology were used to present a fictitious reality which contrasted enormously with the real conditions of the people. They were admonished to suffer the current conditions of life in order to work towards the "bright future of socialism" which always seemed very far off, at least until Stalin had died and some limited reforms were instituted under Kruschev. The Ukraine was a particularly brutal example of forced collectivisation in part due to its importance for agriculture and also the strong mentality and traditions of the peasantry for which the whole peasant body - not just the kulaks - had to pay a high price.

\section{Acknowledgements}

MODSCAPES is a collaborative research project funded under the HERA - Humanities in the European Research Area 3rd Joint Research Programme dedicated to "Uses of the Past" (20162019). This project has received funding from the European Union's Horizon 2020 research and innovation programme under grant agreement $n^{\circ} 649307$

\section{Short resume}

Oksana Zhukova MSc is a Ukrainian architect and landscape architect currently a junior researcher at the Estonian University of Life Sciences.

\section{References}

1. KULCHYTSKY, S.V. 2013. "Український Голодомор у контексті сталінської 'революції згори' " [Ukrayins'kyy Holodomor u konteksti stalins'koyi 'revolyutsiyi z-hory' / Ukrainian Holodomor in the context of the Stalinist 'revolution from above'], Український історичний журнал [Ukrayins'kyy Istorychnyy Zhurnal / Ukrainian Historical Journal], $\mathrm{n}^{\circ}$ 6: 18-44.

Retrieved from: http://resource.history.org.ua/publ/journal_2013_6_18 [available on 1 February 2019].

2. MAROCHKO, V. 2007. Голодомор 1932m-1933 рр. [Holodomor 1932-1933], Kiev. Retrieved from: http://resource.history.org.ua/item/0009840 [available on 1 February 2019].

3. ROMANOVA, P.; YARSKOI-SMIRNOVOI, E. 2007. Советская социальная политика 1920-1930-х годов: идеоло-гия и повседневность [Sovetskaya sotsialnaya politika 1920-1930-h godov: Ideologiya i povsednevnost' / Soviet social policy of the 1920s-1930s: ideology and everyday life], Moscow, ООО «Вариант». Retrieved from: https://www.academia.edu/5504858/Советская_социальная_политика_1920_ 1930-х_годов_идеология_и_повседневность [available on 1 February 2019]. 
4. HORIZONT (1989). $\mathrm{n}^{\circ} 1$.

5. YAKOVLEVA SOST, A.; ARTIZOV, A.N.; NAUMOV, O.V. 1999. Власть и художественная интеллигенция: Док. ЦК РКП(б) - ВКП(б), ВЧК - ОГПУ НКВД о культурной политике 1917-1953 [Vlast' i khydozhestvennaya inelligentsiia /Power and the artistic intelligentsia, Dokementy ZKRKP(b) - VKP(b), VChK - OGPU - NKVD o kyl'tyrnoi politike 1917-1953 / Documents of the Central Committee of the Russian Comunist Party - All-Union Communist Party of Bolsheviks, VChK - OGPU - NKVD on cultural policy 1917-1953], Moscow, Демократия [Democracy].

6. Октябрь: Лит.-худож. и обществ.-полит. ежемес. журн [OKTYABR': literaryartistic and socio-political monthly journal] (1988). $\mathrm{n}^{\circ} 1$.

7. KULCHYTSKY, S.V. 2007. "Голодомор 1932-1933 рр.: механізми сталінського терору" [Holodomor 1932-1933: Mehanismy Stalins'kogo Terroru / Holodomor 1932-1933: The mechanisms of Stalinist terror], Український історичний журнал [Ukrayins'kyy Istorychnyy Zhurnal / Ukrainian Historical Journal], ${ }^{\circ}$ 4: 4-26. Retrieved from: http://resource.history.org.ua/publ/journal_2007_4_4 [available on 1 February 2019].

8. PROCYK, O. ; HERETZ, L. ; MACE. J.E. 1986. Famine in the Soviet Ukraine 19321933: A Memorial Exhibition, Cambridge (MA), Harvard College Library: 28. 